\title{
Ghosts of the Gulag in the Eveny World of the Dead
}

DOI:

10.1080/2154896X.2017.1329256

\section{Document Version}

Accepted author manuscript

Link to publication record in Manchester Research Explorer

\section{Citation for published version (APA):}

Ulturgasheva, O. (2017). Ghosts of the Gulag in the Eveny World of the Dead. The Polar Journal, 7(1), 26-45. [2154-8978]. https://doi.org/10.1080/2154896X.2017.1329256

\section{Published in:}

The Polar Journal

\section{Citing this paper}

Please note that where the full-text provided on Manchester Research Explorer is the Author Accepted Manuscript or Proof version this may differ from the final Published version. If citing, it is advised that you check and use the publisher's definitive version.

\section{General rights}

Copyright and moral rights for the publications made accessible in the Research Explorer are retained by the authors and/or other copyright owners and it is a condition of accessing publications that users recognise and abide by the legal requirements associated with these rights.

\section{Takedown policy}

If you believe that this document breaches copyright please refer to the University of Manchester's Takedown Procedures [http://man.ac.uk/04Y6Bo] or contact uml.scholarlycommunications@manchester.ac.uk providing relevant details, so we can investigate your claim.

\section{OPEN ACCESS}




\section{Ghosts of the Gulag in the Eveny World of the Dead}

ABSTRACT: The article explores the legacy of the Gulag $^{1}$ in Northeast Siberia by providing a detailed discussion of the space of the village built on the former site of the concentration camp haunted by the unhappy ghosts of former prisoners. Since, in local cosmology the latter are given the status of malevolent spirits - arinkael -, they create the context in which the memory of the Gulag is reproduced locally through the repetitive encounters of ghosts in the village buildings. The account illustrates that ghosts of the former violently killed Gulag prisoners charged with affective potential for contagion expand and modify the status of arinkael within the Eveny cosmology. This contributes to the process of "world-making", in which the local population and Gulag ghosts are mutually expanding Eveny cosmology while simultaneously reactivating the memories about the Gulag.

Key words: Siberia, Gulag, Eveny, ghosts, personhood, affect, contagion

${ }_{1}$ GULAG stands for the State Administration of Camps (Gosudarstvennoie Upravlenie Lagerey). It was an enormous organization within NKVD (People's Commissariat for Internal Affairs) that between the early 1930 s and the late 1950 s conducted a political purge affecting practically every citizen in the Soviet Union. The aim of liquidating the "enemies of the people" led to numerous arrests and particularly heavy sentences. NKVD would supply millions of prisoners as a free labour force for large industries and projects throughout the Soviet Union. These included huge timber and gold industries in Siberia and involved the building of important roads such as Kolyma Road, canals (Solovetzky kanal) and railways. In the 1930s the entire production of natural resources and the associated industries came under the remit of GULAG. GULAG prisoners were concentrated in labour camps where they were subject to executions by firing squad, starvation to death, hard labour and epidemics. See Paul R. Gregory and Valery Lazarev, The Economics of Forced Labor (Hoover Institution Press, 2003). 


\section{Introduction}

During several research visits to a village of Siberian Eveny reindeer herders and hunters between 2003-2013, I encountered numerous stories about ghosts told by younger and elder Eveny. Local youth and elders were generously sharing with me their numerous encounters with arinkael (singular: arinka "the spirit of the violently deceased" in Eveny; plural arinkael). While presenting to me their personal accounts of the encounters, almost all of them were consistently pointing to a number of village buildings haunted by arinkael, e.g. house of culture (in Russian $k l u b)$, sports hall, school, village administration, depot, hospital, guest house, heating station, and specific flats in several two-story wooden houses. The witnesses informed me that if the encounter happens once in a place inhabited by people, for example in a flat in a two-story village building, the ghost will continue appearing there until the inhabitants vacate the flat. Their testimonies were accompanied by detailed descriptions of images and the identities of arinkael.

The first detailed testimony which I documented in autumn 2003 was presented by a local 19-year-old Eveny man, Kolya whose account goes as follows:

There are lots of arinkael here, this place is just swamped with them ... there are two 
old, Russian zechki [female prisoners] in the klub [house of culture]. Once they scared my brother Misha who was playing a hide-and-seek game and decided to hide in the attic of the house of culture; he told me that when he was quietly sitting in the corner of attic those women scared him to death ... also in school there are several ghosts of $z e k i^{2}$, they $-z e k i-$ are always walking around there at night, when it is dark and empty ... Then, nearby where I live, there is a village depot, in that depot there is a ghost of a boy in telogreika ${ }^{3}$, it is just scary! ... Then, there is an old woman in a former building of the local heating station, she scares everyone by chasing after them ... Another ghost-zek lives in Auntie Iza's flat, people say that she recently kind of went mad because people heard her speaking to that man. My elder sister told me that Iza herself seemed to have turned into an arinka since she has been lately drinking like crazy on her own. Also, in a guest house people see an old Russian prisoner with a white beard. It once scared the wife of a former head of village administration when they first arrived in the village. After she saw that scary man twice, she left the village promptly and never came back. That man [head of village administration] did not stay long either.

Kolya's story puzzled me profoundly as all his descriptions of the ghosts of zeki (in English 'prisoners') were not only invoking eeriness and spookiness of the entire locality of the village but, given a long period of silence and repressed status of memory about Gulag, they were astonishingly direct in bringing an immediate and unprompted reference to the tragic past.

\footnotetext{
2 Zeki or zakluchennyie is a generic Russian term for 'inmates' or 'prisoners'.

${ }^{3}$ Telogreika - a Russian term for uniform worn by prisoner population
} 
Equally significant, Kolya's testimony vividly reproduced the local perception of the space of the village, which for the last ten years has experienced drastic outflow of the population, leaving empty houses and buildings behind.

In this article I examine Kolya's testimony further by considering the local population's encounters with the ghosts of former Gulag prisoners. The village which I shall discuss here was built on the territory of a former Stalinist labor camp in the 1970s and is considered particularly accursed, haunted by the ghosts of former inmates. I explore how the Eveny reindeer herders perceive the locality saturated with the Gulag past and what ontological properties and cosmological status local Eveny attribute to ghosts of former Gulag prisoners in their world of the dead. Drawing from Durkhemian notion of contagion, Deleuze and Guattari's concept of affect and Eveny theory of 'open body' I shall argue that it is the concept of arinkael that grants Gulag ghosts affective potential for contagion, and it is the Gulag ghosts' power of affect that perpetuates the position of arinkael within the cosmology of the Eveny. Gulag ghosts and Eveny mutually expand the purview of the Eveny cosmology while participating in the process of spatial construction through cosmological alteration of the relationship between the living and the dead.

In the discussion that follows I first provide historical background for understanding of local perceptions of the space of the village by paying attention to the history of local Gulag. Then, I explore the place of arinkael in emic cosmology and views on violent death among Eveny in order to illustrate what impact a Stalinist labour camp had on Eveny cosmology. Next, I proceed to the discussion of how presence of Gulag ghosts/arinkael in the village buildings forces local people to abandon their flats in these buildings in order to give space to the "needy" and powerful dead. Finally, I discuss the Eveny concept of "open body" (angati aerteng) to shed 
light on what constitutes the condition of vulnerability and susceptibility of a human being to the affective influence of malevolent spiritual beings; and how and in what way a living person becomes subject to contagion by the spirits of violently killed dead. The discussion shows that it is human fear of irreversible metamorphosis as a result of Gulag ghosts' contagion that lies in the perception of the village as a contaminated space (in Eveny ningichepche tor). I conclude by discussing a scenario of cosmological entrapment to assist in our understanding of the contemporary resurgence of memory about the Gulag in the area where contemporary Eveny reside.

In the anthropological literature the post-socialist transformations are discussed in terms of intensification and propagation of spiritual practices related to the recent dramatic changes implicated by the collapse of the socialist state ${ }^{4}$. These attempts to understand postsocialist transformations view Soviet religious repressive policies, the collapse of the socialist state and post-socialist neoliberal reforms as social and ideological prerequisites for proliferation of religious practices. Drawing from creative attempts by people to make sense of a profound experience of uncertainty and socio-economic instability, the anthropological accounts illustrate a wide range of social and cultural responses to the collapse of the socialist system. However, my

\footnotetext{
4 Marjorie Balzer ,"Dilemmas of the Spirit," In Religious Policy in the Soviet Union (1993): 231-251 (Cambridge University Press); Marjorie Balzer, Tenacity of Ethnicity Siberian Saga in Global Perspective (Princeton University Press, 1999); Nikolai Ssorin-Chaikov, Social Life of the State in Subarctic Siberia (Stanford University Press, 2002); Manduhai Buyandelger, Tragic Spirits (Chicago University Press, 2013); Morten Pedersen, Not Quite Shamans: Spirit Worlds and Political Lives in Northern Mongolia (Cornell University Press, 2011); Katherine Swancutt, "The Undead Genealogy: Omnipresence, Spirit Perspectives, and a Case of Mongolian Vampirism," In Journal of the Royal Anthropological Institute 14, no. 4 (2008): 843-64; Katherine Swancutt, "Masked Predation, Hierarchy and the Scaling of Extractive Relations in Inner Asia and Beyond", in Animism in Rainforest and Tundra: Personhood, Animals, Plants and Things in Contemporary Amazonia and Siberia (2012): 293-326 (Berghahn Books); Swancutt, Fortune and the Cursed (2012).
} 
account will demonstrate that the ghosts of the Gulag prisoners (arinkael) are not only a metaphor through which locals articulate their responses to dramatic post-socialist changes, they are spiritual residues of the violent past that continue to re-constitute and reproduce the space of the village as a former territory of the Gulag camp contaminated by violence. I shall illustrate how ghosts hold a powerful position in the asymmetry between the living and the dead and by doing so perpetuate the status of arinkael within the Eveny cosmology.

\section{Eveny and Gulag}

Eveny are a minority people of Northern Asia who number around 17,000 and speak a TungusManchu language. Most Eveny live in northern Siberia and engage in a double economy that combines reindeer herding and hunting/fishing. In pre-Soviet times Eveny clans and families moved along traditional hunting routes and across vast territories of reindeer pastures relatively unconstrained $^{5}$. In the early 1930s the new Soviet regime launched the process of sedentarization as part of the Soviet project of modernizing the Russian Far North. The close proximity of Eveny reindeer herders to large Soviet construction projects such as YanStroi, YanLag and Magadanskaya trassa (widely referred to as the Road of Bones), and the Stalinist labor camps which stretched across the area, made them subject to an enforced process of relocation into artificially created villages. In the case of the particular community that I discuss, in the 1970s the local population was pushed into a village on the territory of a former Gulag camp.

Prison camps within $300 \mathrm{~km}$ of the village were engaged in building one of the branches of the Road of Bones. The construction of the road was one of the Gulag projects termed Dalstroi (Far Northern Construction Trust), which was headquartered in the Russian far

${ }^{5}$ Forsyth, A History of the Peoples of Siberia (1994). 
eastern city of Magadan ${ }^{6}$. The plan to construct a long-distance road was confirmed by Stalin in the 1940s, during the Second World War, and it was to be used for transportation of raw materials for Soviet military factories. It was built with the forced labour of Gulag prisoners until the late $1950 \mathrm{~s}-1960 \mathrm{~s}$.

Along the road, labour camps were located 20-25 km apart on flat expanses, and every $10-15 \mathrm{~km}$ from each other in mountainous areas. One camp was located on the site of the present-day Eveny village,. The authorities chose the territory of a former labour camp as a suitable location for a village because of its close position to the supply road. From the Soviet perspective, the villages like the one under consideration were designed as a totally rational space. They were to epitomize and embody the Soviet idea of development expressed as "mastering" the territories of the Russian Far North". The relocation of the local Eveny population from numerous nomadic camps and tiny hamlets to a new village started in the 1970s and was especially disturbing for locals, given that it was formerly a concentration camp where prisoners were tortured and died.

Among the Eveny, relocation or movement to a place that was formerly occupied by others is conceived as an intrusion into an already inhabited space, i.e. spaces inhabited by the "traces" of former inhabitants ${ }^{8}$. A space which contains such a trace is believed to be contaminated and accursed because a violently killed human stays in the world of the living in the form of a ghost, or arinka. The presence of an arinka automatically implies that there was a death caused by violence in the vicinity, and that arinka may harm or bring misfortune to living

${ }^{6}$ Gregory and Lazarev, The Economics of Forced Labor (2003).

${ }^{7}$ Slezkine, Arctic Mirrors (1994); Ssorin-Chaikov, Social Life of the State in Subarctic Siberia (2002).

8 Ulturgasheva, Narrating the Future in Siberia (2012); Ulturgasheva, "Spirit of the Future: Movement, Kinetic Distribution and Personhood”, Social Analysis 60, no.1: 56-73. 
intruders. Therefore, the local population conceived their experience of relocation in the 1970s as a dangerous intrusion into a space inhabited by unhappy dead, i.e. unburied, violently killed prisoners of the Gulag camp?

In the aftermath of collapse of the Soviet infrastructure and the resulting abandonment and isolation of the community due to withdrawal of state support, encounters with Gulag ghosts by natives intensified. Nowadays the space of the village harbours a precarious co-existence of the violently killed dead and the coercively relocated living. This unhappy and volatile coexistence is exacerbated by living memories of the prisoners' demise and numerous encounters with ghosts of former prisoners by locals in the buildings of the village.

\section{Memory about Gulag}

Recent memory studies demonstrate how remembrance of mass violence has taken various forms, ranging from heroism and the politics of victimization to collective silence and selective amnesia $^{10}$. In Russia, memories of the Gulag and the catastrophic suffering experienced by millions have not yet received elaborate interpretation. Though traces are visible, mostly in literature and other artistic forms, they remain at the edges of public discourse, and despite a very short period of condemnation of the Stalinist mass repressions in the early 1990s, they continue to be widely ignored or denied ${ }^{11}$. Jehanne Gheith distinguishes several historical reasons for the

\footnotetext{
${ }^{9}$ Ulturgasheva Narrating the Future in Siberia, 131.

${ }^{10}$ Antze and Lambek, Tense Past (1996); Lambek "Memory in a Maussian Universe", In Memory Cultures: Memory, Subjectivity and Recognition, (Transaction Books, 2006; Lambek, The Weight of the Past (2002); Carsten, Ghosts of Memory (2007).

${ }^{11}$ Gheith and Jolluck, Gulag Voices (2012); Ulturgasheva, "Gulag Legacy: Spaces of Continuity in Contemporary Everyday Practices", in Laboratorium. Thematic issue: Gulag legacy: Spaces of Continuity in Everyday Practice 7, no 1: 5-14; Ulturgasheva, "Haunting Afterlives of the Gulag in the Siberian Sub-Arctic" (2016).
} 
silence and denial ${ }^{12}$. One of them is that, for seventy years, Gulag survivors risked severe punishment for talking about their experience in Stalinist labour camps: thus, there was a long silence about the Gulag until the late 1980s-early 1990s. While citing Russian historians, Gheith

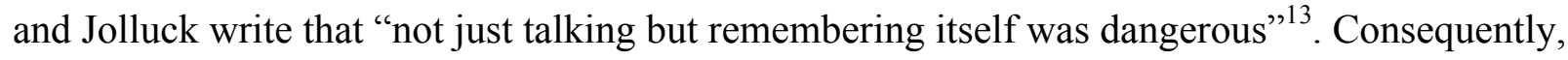
there has been no chance for these memories to reach the point of recognition, reconciliation and recovery.

In the domain of memory studies, and specifically memories of the Gulag, there is a particular methodological challenge in dealing with the issue of evidence, namely how to make sense of, interpret and analyse the tragic, traumatic and coercively silenced past when ethnographic studies are literally absent, the archival evidence is inaccessible, available statistical or historical data are inaccurate and chaotic, and empirically rich accounts focusing on unmediated experiences of Gulag inmates are scarce or nearly absent. Taking this challenge into account, I propose an epistemological shift from a methodological focus on incomplete archival, historical evidence as well as unrecognized and unauthorized memories to those socially grounded, interactive processes in which the traces and debris of the Gulag, both material and immaterial, participate as "world-constituting" or "world-making" components ${ }^{14}$. These socially grounded interactions, i.e. "world-making" dynamics, may shed a new light on the studies of memory about Gulag, which tend to put up unnecessary barriers between past, present and future by focusing on practices of remembrance through the lens of historical, genealogical reasoning. Such a shift in methodological focus may also assist in avoiding interpretations from the

\footnotetext{
${ }^{12}$ Gheith, "I never talked": Enforced Silence, Non-narrative, Memory, and the Gulag", Mortality 12, no. 2 (2007): 159-75.

${ }^{13}$ Gheith, Gulag Voices, 7.

${ }^{14}$ Kapferer, "Introduction. Outside All Reason: Magic, Sorcery and Epistemology in Anthropology", Social Analysis 46, no. 3 (2002): 1-30
} 
territorialized, linear viewpoint inherent to historical interpretation and reproduction, and prevent the risk of reproducing positivist chronology that often contributes to a perilous enterprise of essentialization and reification of the new type of memory ${ }^{15}$.

Hence, this article centers on the continuity of the unresolved Gulag past in the present and the ways it manifests, unfolding itself through participation in the dynamic process of cosmological expansion of a specific category of local spirits. The case of memory about the Gulag which I present here is characterized by the absence of any conscious human effort to reconstruct the past. Instead, the figure of a ghost - arinka - holds a special place in nomadic cosmology and enforces a particular type of human engagement with the tragic past engulfed by mass violence.

\section{Unnatural participation}

In the anthropological literature on Siberian Tungus groups ${ }^{16}$ it is often emphasized that violent death is viewed not only as an event that profoundly disturbs the community of the living, but also as an unsettling incident which produces ghosts, i.e. "tangible creatures with human form but not human substance" ${ }^{\prime 17}$. In his discussion of piacular or atonement rites Durkheim highlighted that the distressing event of violent death is thought to generate malevolent forces ${ }^{18}$, i.e. spirits of the dead, imps, devils, vampires or ghosts, whose intense and contagious power

\footnotetext{
${ }^{15}$ Lambek, The Weight of the Past, 210; Argenti and Schramm, Remembering Violence: Anthropological Perspectives on Intergenerational Transmission (Berghahn Books, 2010). ${ }_{16}$ Bogoras, Lamuty (1900); Jochelson, The Yukaghir and the Yukaghized Tungus (1926); Shirokogoroff (1935); Popova, Eveny Magadanskoi Oblasti (1981); Vitebsky, Reindeer People (2005); Sirina, Eveny i Evenki v sovremennom mire (2012).

17 Mauzé, Marie, "The Concept of the Person and Reincarnation among the Kwakiutl Indians", In Amerindian Rebirth: Reincarnation Belief among North American Indians and Inuit (University of Toronto Press, 1994: 177-91).

18 Durkheim, The Elementary Forms of Religious Life (1912).
} 
threatens the well-being of the living unless they are disarmed and assuaged by an expiatory rite $^{19}$.

By paying attention to testimony and to the non-discursive perceptions I argue that the mass deaths perpetrated during the $20^{\text {th }}$ totalitarian era in Siberia have generated 'ghosts' which require further and more sufficient forms of understanding to those proposed by Durkheim. In his discussion of contagiousness of the sacred Durkheim draws a qualitative boundary between the sacred and profane worlds which should remain antagonistic, mutually exclusive and apart from each other. Here contagion is perceived as contamination of the profane (living) by the sacred (dead), i.e. the propagation of religious, spiritual forces through an infectious contact ${ }^{20}$. He writes that "there is always a possibility for the sacred world to infiltrate that same profane world it otherwise excludes. Even if it repels it, it tends to flow into it as soon as it comes near". Durkheim emphasizes a remarkable aptitude of the "sacred" to contaminate the profane as it spreads from the contaminated object to all those it finds in proximity or physical contiguity ${ }^{21}$.

In this account I would like to expand the Durkheimian notion of "contagion" by suggesting that the boundary between the sacred and the profane might be understood not only in terms of separation set by a human collective but by the dynamic that works the other way around. In other words, I argue that it is the former space of the concentration camp and the ghosts of its violently killed prisoners (the sacred) rather than living humans (the profane) that contribute towards further separation of the sacred from the profane within a cosmology which

\footnotetext{
${ }^{19}$ There is considerable variation in the way living humans cope with the phenomenon of ghosts across cultures and religions (Kan, Symbolic Immortality Symbolic Immortality (1989); Gordillo, Landscapes of Devils (2004); Kwon, Ghosts of War in Vietnam (2008); Swancutt, "The Undead Genealogy").

20 Ibid., 240-1.

21 Ibid., 237.
} 
has mainly worked towards social integration and accommodation of spiritual forces through the means of rituals and spatial organization. In short, if the living humans work towards social integration and accommodation of the spirits of the dead, ghosts of the Gulag separate themselves by rejecting the efforts of the living humans. The latter adds another dimension to Durkheim's notion of contagion by showing that it is the unquiet dead who expand their territory while it is the living humans "who are in danger of losing their distinctive and necessary

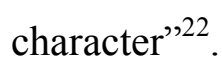

Since the Gulag ghosts are given the status of arinkael in Eveny cosmology, they inadvertently participate in the process of spatial production, i.e. they create the context in which the memory of the Gulag is reproduced locally through repetitive appearance of ghosts of Gulag prisoners (arinkael) in the village buildings. This context shapes local perception of ningichepche tor (locally referred to as an accursed or contaminated space, full of arinkael) whose contagious power is believed to pull living people into the world of the dead.

If the concept of arinkael expands Durkheiman notion of contagion, it is the theoretical notion of affect developed by Deleauze and Guattari ${ }^{23}$ that I find the most helpful in revealing local perceptions of the space of the village. Their notion of affect, defined as "pre-personal, prereflective bodily responses expanding or diminishing a body's capacity to act" 24 , is relevant because it subverts the linear perception of the events and helps to illustrate the impact exerted by Gulag ghosts on the contemporary Eveny perception of the space of the village. In this particular case, affect is generated by material and visible traces of the Gulag, i.e. abandoned or recycled buildings of prisoners' barracks, execution spots including fences with barbed wire and

22 Ibid., 26-7.

${ }^{23}$ Deleuze and Guattari, A Thousand Plateaus (1987).

24 Ibid., xvii 
watch towers, and, specifically, association with the visible traces of ghosts of Gulag prisoners. The main attribute of the latter, i.e. their unnatural, violent death, implies that they have a potential power to transmit death to all those who come into contact with them; even the location where violent death happened is permeated by specific carriers of contagion, i.e. ghosts of the violently killed dead.

Moreover, I view notions of affect and contagion as specially intertwined and presented as co-implicated in the discussion of "unnatural participation" by Gilles Deleuze and Félix Guattari ${ }^{25}$. The concept of "unnatural participation" which comes out of the thesis that "the vampire does not filiate but infects" refers to propagation and expansion of social forms by contagion which Deleuze and Guattari contrast with "filiative production or hereditary reproduction" 26 . The 'unnatural participation' is a generative notion for this analysis as it furthers Durkhemian take on contagion by illuminating the social scenario within which living captives are entangled in unwanted assemblage with the powerful dead. The mode of such participation will conjure a connection to the local scenario of 'cosmological entrapment'. I shall give a detailed consideration of the latter in the concluding part of the article.

First, let me discuss what actually happens in the village, where proximity to the world of the dead is dangerously close.

\section{The space of a former Gulag camp}

From the Soviet perspective, the village was created as part of the Soviet civilizing mission to serve as a proxy for the wider world of the Soviet Russia. In the village, the Eveny sense of a

\footnotetext{
25 Ibid., 265-73.

${ }^{26}$ Ibid., 267.
} 
nomadic camp (domngae) and the locality of a former Gulag camp (lager') have merged into one. The village appears to be a large camp in two senses. It is a container of previous people's traces in the Eveny cosmology and it is also a former Soviet concentration camp for Gulag prisoners. Two types of the dead, i.e. local and foreign, inhabiting the same space, became conflated into one type of spirit - arinkael.

Since in the past arinkael were mainly encountered in the forest, it seems that they were also made sedentary and concentrated in the village just like the humans. Now I would like to return to Kolya's account reproduced earlier. His testimony contains several points important for my further discussion: 1) specifically, Kolya's reference to his Auntie Iza who, as a result of frequent interaction with the ghost of the prisoner, undergoes gradual transformation into one of the arinkael or what I call an irreversible metamorphosis as a result of contagion; 2) then, the desire of the arinka to chase after the living and Kolya's list of the village buildings inhabited by the Gulag ghosts will exemplify the scenario of cosmological entrapment that I put under consideration further.

Following Kolya's detailed description and identification of ghosts and the location of the venues inhabited by them, I examined existing documentation to reproduce the former concentration camp cartographically. Historical published material on this particular part of the Gulag that gives accurate historical data is lacking, apart from some oral accounts of Gulag survivors (poselenzty in Russian) recorded and archived by local volunteers from the small museum of Kolymskaya Trassa situated in one of the Dalstroi towns. In 2011 when I was examining the content of the tiny museum I accidentally found a copy of a map of the concentration camp on which the present village stands. If I had a chance to take a picture or a copy of that particular map at that moment, it would have served as a rare piece of historical 
evidence and valuable source of ethnographic data. However, upon my return two years later I was devastated to learn from local authorities that the entire content of the museum was lost during severe flooding in 2013. A yellow, warn-out map was astonishingly precise at pointing at the current location of the buildings listed by Kolya as it turned out that those spots where the local house of culture and the gym are now located served as a ground where prisoners were executed. The village depot used to be a barracks that contained several isolation cells where prisoners were tortured, starved, or frozen to death. I should note that the Gulag prisoners were never buried properly; instead, they were thrown into a communal hole or their bodies were used as fillers in the Road of Bones. The memoirs of one former Gulag prisoner who miraculously survived several years in one of the YanStroi camps mention that extremely low temperature and permafrost replaced the need for the crematoriums used in Nazi concentration camps, and dead bodies would be put into the foundations of the $\operatorname{road}^{27}$.

This partial reproduction of the space of the camp suggests that the local perception of the village as an accursed space verifies the historical fact that Gulag past is sedimented within the topography of a former concentration camp. As cosmological agents and contaminating force, the ghosts of the former Gulag prisoners are actively engaged in the reproduction and construction of a sense of space in the present exemplifying the afore-mentioned scenario of "unnatural participation" which propagates itself through affect produced by the ghosts.

\section{Arinkael and Gulag ghosts in Eveny cosmology}

${ }^{27}$ Fedorov, "Vorota v Kolimsky ad," Yakutia 7 (2001), no.20: 5. 
Ethnographies detailing Eveny cosmology show that ideas about the spirits of the dead arinkael (malevolent spirits of the violently killed dead), bunil (benevolent ancestor spirits), magdili (evil spirits both of human and non-human origin) -are very detailed and elaborate, and that these kinds of spirits have always caused fear and distress ${ }^{28}$. In his account of Eveny in the village of Sebyian, Vitebsky ${ }^{29}$ points to a prominent characteristic of Tungus cultures which is concerned with the traces left behind by human activity. He shows that any physical objects used by people who have since died, e.g. fence poles or the ropes used to tie their animals, are, by definition, haunted because they are the sites of the deceased person's life and related to their life events. In the same vein Lavrillier ${ }^{30}$ has also shown that the biggest concern among the Evenki ${ }^{31}$ of the Amur region is not to leave a "footprint" (onnir in Evenki) after oneself. The nature of this concern points to previous events which may potentially bring misfortune to those who may be harmed by traces left behind, since these occupy space which has already been claimed by others. According to this cultural logic, the world of the living and the world of the dead are entangled and entwined within the intricate web of traces of human and non-human forms.

Arinkael is the Even name for malevolent forest spirits ${ }^{32}$. These are former human beings who by virtue of their accidental, violent deaths have had the unfortunate posthumous destiny of remaining in the world of the living, wandering around in the forest, chasing after the

\footnotetext{
${ }^{28}$ Nikolaev, Eveny i evenki jugo-vostochnoi Jakutii (1964); Popova, Eveny Magadanskoi oblasti (1981); Shirokogoroff, Psychomental Complex of the Tungus (1935).

${ }^{29}$ Vitebsky, Reindeer People (2005).

${ }^{30}$ Lavrillier, "Nomadisme et adaptations sédentaires chez les Evenks de Sibérie post soviétiques," (Unpublished PhD Thesis, Paris, Ecole Pratique des Hautes Etudes, 2005).

${ }^{31}$ Both Eveny and Evenki belong to the Tungus language group and share the same ethnic roots (see Sirina, Eveny i Evenki v sovremennom mire (2012); Vitebsky, Reindeer People (2005) Ulturgasheva, Narrating the Future in Siberia (2012).

${ }^{32}$ Shirokogoroff, Psychomental Complex of the Tungus (1935); Popova, Eveny Magadanskoi oblasti (1981); Sirina, Eveny i Evenki v sovremennom mire (2012).
} 
living and disturbing the lives of the living by bringing them misfortune ${ }^{33}$. Arinkael are also part and parcel of the nomadic perception of human engagement with an accursed space. Since local Eveny refer to the locality of the former concentration camp as ningichapechae tor ("the place which is rotten, contaminated and accursed") I argue that it is also the contagious potential of the locality that contributes to cosmological expansion of arinkael.

Among the Eveny, spaces of both forest and village contain the potential spots of dangerous contagion which may come from arinkael who are prone to communicating contagious spirithood of the dead to the living humans. That is why, in the forest, one must follow various taboos and conduct small rituals to prevent oneself from getting entangled and trapped by the disturbed dead. If one accidentally engages with an unhappy spirit one risks getting involved in a relationship with it. The other Eveny taboo or tonkaekich (udji edji aemaen) is "don't leave a trace or footprint after yourself." The main purpose of this kind of prohibition ton 'kaekich (the Even word ton 'kae can be literally translated as "respect") - is to prevent humans from allowing their traces to become entwined with the traces of previous humans. However, if seeing an arinka happens in the forest, people are able to avoid and pre-empt the situation of engagement with it by not even looking at it and moving on from the event as fast as possible. The strategy is not to engage yourself with it, even with your eyes. They often emphasize that even quick eye contact with arinkael has grievous consequences - the eye contact can eventually lead to a misfortune and even a victim's death. For example, one experienced reindeer herder told me a story about the consequences of an encounter with an evil spirit, arinka, on the territory of a former concentration camp located on the route of seasonal migration of his reindeer herd. His oral testimony that I recorded in 2010 goes as follows:

${ }^{33}$ Ulturgasheva, Narrating the Future in Siberia, 133-9. 
If you need to pass that place, you'd better do it very quickly without stopping and without even looking in the direction of the place. There is always a possibility that you can see a candle while passing it. If one takes even a slight look of the candle, an arinka comes out of the abandoned house - it's really bad if it happens to you. And all reindeer herders are scared of the place because of what happened to my old friend. Once he was passing that place and he didn't know about the arinka. He looked in the direction of the site where he saw a candle. He wondered why the candle was in an abandoned site and who it might be. But when he was just about to pass the place, some person came out of the house, reached his caravan and sat on the last sledge. His caravan stopped and however hard he tried to make the reindeer move, they couldn't move because somebody heavy was sitting on the last sledge and wouldn't allow his caravan to move. It was really dark and he couldn't see anything apart from a dark shadow sitting on the sledge. My friend struggled with immovable reindeer for some time and only after the arinka stood and went back to its dark house was he able to leave the place. All this time he was terrified, that is why he drove his caravan like crazy until he reached his encampment. He was very scared by what happened to him; soon after he fell ill and died. That is why, right before passing this locality, I always stop, smoke a cigarette, give my reindeer a chance take a breath before I charge them heavily in order to pass that place as quickly as I can.

The account of a herder's contact with an arinka illustrates the asymmetry of the positions within the dyad of the living and the dead in which the latter takes control over the 
former and eventually pulls the living into the world of the dead ${ }^{34}$. Moreover, emphasis on visual contact and its repercussions suggests that the malevolent spirit gradually starts drawing the victim into a circle of its contagious power through its initial engagement by eye contact until the spirit takes entire control over the victim. In the Eveny scenario of interaction between the living and the arinkael it is possible to observe that the main emphasis is made on the dangerous repercussion of any contact that may lead the living to contagion by the powerful dead. Therefore, while facing close proximity to the contagious spirits of the dead, the local person is afraid to be entangled into an unwanted relationship with the dead. Since the latter strives to enclose the victim into its full control and containment, this suggests that the relationship between the living and the dead is essentially an asymmetric one in which the living hold the inferior position while the dead are viewed as superior, powerful entities. Such instances of asymmetric exchange between the living and the dead remain to be associated with the concept of "open body" which I find highly important for this analysis.

\section{"Open body"}

In the case of Eveny contacts with arinkael, human avoidance of any engagement with the spirits suggests that contact with living humans is desperately sought by arinkael who aspire to transform the living into one of them. Fatal repercussions of such contact for living humans may include their sudden disappearance in the forest while travelling on the way to the human camp. If after several weeks of search the body is not found, a person is viewed as "lost to the arinkael," which implies that a person has lost a sense of his/her human identity and has been

${ }^{34}$ Willerslev, R. and O. Ulturgasheva, "Revisiting Animism versus Totemism Debate", In Animism in Rainforest and Tundra: Personhood, Animals, Plants and Things in Contemporary Amazonia and Siberia (2012): 51-8 (Berghahn Books). 
transformed into an arinka. Such occasions have been quite rare, because, in order to reach the point of intense contact with arinkael, a person would have to be particularly susceptible to these malevolent spirits. This degree of vulnerability or susceptibility to contagion is expressed in the concept of "open body" (angati aerteng in Eveny).

The condition of "open body" points to a weak connection between soul and body, which makes the soul unable to resist attacks by the predatory spirits, who are quite likely to succeed in capturing such a person. The state of having an "open body," translated as a fragile, unprotected and volatile "soul," is dangerous and rare for an adult human as it is usually newborn children who have "open bodies." The early stage in the human lifecycle is perceived as the most precarious and is defined as having an "open body" - angati aertang ${ }^{35}$. The "open body" is thus the essentially frail body of a newborn child, which requires a means of protection such as a khavek (guardian reindeer), and a proper name. Both prevent a vulnerable child from attacks of malevolent spirits attracted by a child's "open body". In the process of a child's development, the state of "open body" moves into the stage when the "body" reaches its "closure," which usually happens in adolescence. If the "closure" does not happen for some reason it means that an adult's "open body" will continue to attract the malevolent spirits. Having a "closed" body is crucial, as it serves as a protective shield against dangerous contact with the spirit world and also ensures that the likelihood of contact with arinkael is fairly low. The Eveny concept of the "open body" thus denotes a view of arinkael as spirits that can overpower a living human and turn him or her into one of them. Thus, the reason for living people's view of these spirits as malevolent lies in their expectation of the predatory mode of exchangeability in which the Gulag

35 Vitebsky, Reindeer People, 111; Willerslev, Soul Hunters (University of California Press, 2007). 
ghosts or arinkael, possess powerful potential for triggering irreversible metamorphosis. Given that the encounters with arinkael have recently become widespread, it seems that the number of living "open bodies" has increased, as even those who considered themselves as having "closed bodies" started seeing ghosts of Gulag prisoners. One of my interlocutors, 18-year-old Misha, had never considered himself an "open body" when once he saw a ghost of a young male zek with blue eyes and blond hair in the hall of the local gym. His testimony which I collected in 2009 goes as follows:

In the village I would usually play volleyball in the gym and one evening we played longer than usual. When the session was over I was responsible for locking the gym so I stayed longer than the rest. When I was just about to leave the building, I suddenly heard that somebody was still inside and running on the stairs. I got furious and wanted to kick that boy out of gym so I ran after him. When I was just about to reach him, he suddenly rushed in a different direction and disappeared under the stairs. I went to check the stairs once again. I suddenly realised that it was a scary ghost whom I had tried to chase. When that boy was standing under the stairs, I noticed he was very thin, and he had blond hair and blue eyes. I got really terrified by his appearance so I literally flew out of the gym within a second. Then, I wouldn't go to the gym for some time - that year I didn't feel happy, I did not feel really myself, and I left the village for the city.

He went on to explain that this encounter with the "ghost" made him realize that his body was no longer "closed" and he was equally as vulnerable as those who had encountered 
arinkael and discovered that their bodies were "open." His sense of "openness" and vulnerability made him literally flee from the space contaminated by the ghosts. He quickly moved to the city after the contact and by doing so saved himself from contagious scenario of "turning into an arinka". His discovery of having an "open body" suggests that physical proximity of the spirits of the violently killed dead serves as a precondition for a person's vulnerability. In this sense, the arinka serves as a dangerous trace that may entangle an "open body" into a contagious relationship with the spirits of the dead.

All of the above entails that affect is produced and intensified through a local person's perception of oneself as an "open body" vulnerable in the face of the contagious force of the unquiet dead. It is an uneasy and precarious affective dyad of a contagious spirit of the dead and a vulnerable "open body" that informs people's response to the locality of the village as an accursed space and reactivates memory of the Gulag repeatedly.

\section{Neediness of ghosts}

The local way of perceiving the ghosts remarkably matches the locals' description of their contacts with the Gulag prisoners in the past (1950s) when they were still serving their punishment around the area. So each encounter of a Gulag ghost by a local person reproduces, in one way or another, scenarios of the encounter of the local population with the Gulag prisoners.

I have come across an account of such contact with the prisoners in the oral recollections of an elderly Eveny lady, who in her youth lived in a small nomadic encampment in the vicinity of the road, which at that time (in the early 1950s) was still undergoing construction, and who once had to travel along the Road of Bones in a group of other locals in a lorry accompanied by military guards. During our conversation she intimated that when she saw the 
prisoners for the first time she found them astonishingly terrifying and referred to them as arinkael - "dark people from the world of the dead." They begged for food, clothes and tobacco from those who happened to pass through the territory of a concentration camp and had the same expression of hunger and desperation as arinkael. Locals gave them whatever they had at that moment, especially tobacco (a treat specially valued by the spirits in the forest). The old lady's reference to arinkael emphasized that the prisoners' behaviour and appearance resembled those of the spirits of the dead, which belong to the domain of the arinkael, and therefore locals responded to their needs by giving whatever they had to hand generously. They would give away their reindeer and sledges to those who attempted to escape from the Gulag, though their attempts were rarely successful owing to extreme weather conditions and rugged landscaoe.

According to elderly poselentsy living in a district centre, 300 kilometers away from the village this particular Gulag camp was classified as one of the secret death camps, i.e. a camp for prisoners who served their death sentence under Article 58 of the Soviet Penal Code which was used for execution of so called politicheskye or political dissidents in Russia. Given the historical background of this particular camp, the local woman's view of the prisoners as "people from the world of the dead" appears to be consistent with the prisoners' status of being literally pre-dead, as they already bore a heavy imprint of death in their appearance.

Hence, what the Eveny lady's account suggests is that the present-day Eveny response to the Gulag ghosts derives from the local strategy of dealing with the desperate pre-dead in the past, when they gave away whatever was requested from them by the prisoners. However, the main problem nowadays appears to be the ghosts' unresponsiveness to such offerings and their persistency in their disturbance of the living. 


\section{Kinship and the dead}

The ways local people deal with disturbances by ghosts reflect a particular perception of the post-mortem taxonomy and a place of violently killed dead within the taxonomy. In his account of the ghosts of war in Vietnam, Heonik Kwon views ghosts "as a vital source of historical evidence (and a cultural witness) of war-caused violent death and displacement of human lives"36. In this sense, the ghosts testify to a violent political history that caused mass displacement. He illustrates how residents of the villages resolve their concerns about the abundance of ghosts of foreign soldiers by incorporating them into the network of ancestral spirits through a special ritual of transformation. This transformative ritual of commemoration and hospitality is meant to move displaced foreign spirits from the sphere of wandering spirits into the domain of familiar ancestral spirits. Kwon suggests that, by doing so, those who engage in social intimacy with displaced spirits create human networks of sympathy and trust with and amongst displaced individuals ${ }^{37}$.

In contrast to Kwon's account, here we may observe a total absence of such effort among Eveny, as Gulag ghosts are not subject to any ritualized form of incorporation. More importantly, their place in the Eveny social universe is given unquestioningly. That is to say, in the Eveny case we are dealing with a cosmologically different post-mortem model, in which the deceased are not placed within a particular kinship hierarchy and ancestor cult as in Kwon's account, and as in other shrine-centred and place-bounded commemoration practices described in a number of Southeast Asian ethnographies ${ }^{38}$.

36 Kwon, Ghosts of War in Veitnam, 32.

37 Ibid., 130-2.

38 Eric Mueggler, The Age of Ghosts (2001); Stephen Feuchtwang, "The Transmission of Traumatic Loss", In Remembering Violence: Anthropological Perspectives on Intergenerational Transmission 2010: 229-50 (Berghahn Books); Swancutt, "Masked Predation, Hierarchy and the 
The Eveny kinship system involves bilateral exogamy based on the principles of both consanguinity and affinity, i.e. kin may be recruited on another principle than "blood," e.g. coresidence, co-migration, commensality or co-production. Quite often, the preference for marrying out remains persistent, and therefore the process of kin-making is directed outwards and works towards the creation of social relations which are meant to be maintained by movement and reciprocity, i.e. regular visits to nomadic camps, or means of exchange such as parcels, food and gifts. Here, social bonds and affinity are construed within a regime of accommodation and "voluntary mutuality" between dependence and autonomy, otherness and non-otherness ${ }^{39}$. Therefore, I suggest that the Eveny taxonomy accommodates rather than incorporates; it provides the space rather than assimilates the "other" into an existing order. This type of cosmological "openness" is also featured in the ethnographic accounts of animist societies throughout the Circumpolar North ${ }^{40}$. Unlike many Southeast Asian groups who resolve the problem of harbouring all deceased outsiders within shrines or "notional" locations for memorializing them, the Eveny case provides an outlook onto groups who unquestioningly incorporate "outsiders" or "ethnic others" into cosmologies that posit a social continuity between the living and dead.

Among the Eveny the spirits of deceased kinsmen are mobile and act as a neighbouring

Scaling of Extractive Relations in Inner Asia and Beyond", in Animism in Rainforest and Tundra: Personhood, Animals, Plants and Things in Contemporary Amazonia and Siberia (2012): 293-326 (Berghahn Books).

${ }^{39}$ Morrow, "Yupik Eskimo Agents and American Legal Agencies", Journal of the Royal Anthropological Institute (1996), no. 2: 405-23; Briggs, Inuit Morality Play (1998); Cruikshank, Do Glaciers Listen? (2005).

40 Bodenhorn, "He used to be my relative": Exploring the Bases of Relatedness among Inupiat of Northern Alaska," in Cultures of Relatedness: New Approaches to the Study of Kinship (2000): 128-48 (Cambridge University Press); Cruikshank, ibid. 
social group that exists in parallel to the ever mobile camp of its living kinsmen. This precarious co-presence obliges living humans to appease the deceased kinsmen through regular offerings, following prohibitions and avoiding the places of residence of the dead. These gestures prevented them from being disturbed and harmed by the dead who always prey on the vulnerable and susceptible living. However, new types of arinkael stand out by their constant neediness and dissatisfaction with the living humans' offerings. What perplexes living people, especially in this village, is the proximity of the arinkael's physical residence and the unavoidability of humans' encounters with arinkael, which have become increasingly frequent in the confined space of the village.

\section{Irreversible metamorphosis}

In the village, the sense of confined space within village buildings only intensifies the affect of arinkael and their contagious power, creating the immediate point of connection with the violent past associated with the Gulag. The intensity and frequency of engagement with the ghosts may suggest that the more often local people encounter Gulag ghosts the more prone to irreversible metamorphosis they become ${ }^{41}$. Alcohol abuse or violence to self and others are believed to accompany such transformations.

According to Eveny eschatology, when a person dies, the soul - han'yan - leaves the physical body. After the han'yan has left, the deceased acquires another soul, which is located in

\footnotetext{
${ }^{41}$ Aparecida Vilaca, "Chronically Unstable Bodies: Reflections on Amazonian Corporalities," Journal of the Royal Anthropological Institute (2005), no. 11: 445-64; Carlos Fausto, "Feasting on People" Eating Animals and Humans in Amazonia, Current Anthropology 48 (2007), no. 4: 497-530; Willerslev, "The Optimal Sacrifice: A Study of Voluntary Death among the Siberian Chukchi, “American Ethnologist 36(2009), no.4: 693-704.
} 
the dead body until the tendons in the joints decompose. This takes place on the seventieth day after death, and around this time the soul is expected to fly to the other world - Buni. But when the person dies violently his/her second soul remains in the world of the living; then it turns into an errant spirit (arinka) and causes disturbance among the living. So it is violent death and the ability to penetrate the boundary between life and death that essentially distinguish arinkael from other dead who do not annoy the living so much and are not interested in impish trespass into the world of their kinsmen. In his detailed discussion of the Siberian Evenki spirit of arenki, which shares the same etymological and conceptual root with the Eveny term arinkael, Sergei Shirokogoroff remarks that:

arenki are described by Evenki as miserable beings: they have only skin and eyes; they have no tobacco or meat and thus they are always hungry for in their food they depend upon the people's generosity. Generally, they are mischievous, especially, where they are found in great numbers, i.e. near graves ... and they always steal meat and make all kinds of trouble for lay people; they whistle, make fires, etc. ... When a person is alone he may see them, but when there are many people these spirits do not show themselves ${ }^{42}$.

The anthropomorphic attributes of the Evenki arenki, and their malicious disposition as well as the fear and anxiety they cause among the living, are consistent with the perception of arinkael among present-day Eveny. Although Shirokogoroff's ethnographic description of the

\footnotetext{
42 Shirokogoroff, Psychomental Complex of the Tungus (1935).
} 
Evenki encounters with arenki is developed within the discourse on physical states of delirium and hallucination, which reduces the spirits' cosmological significance to physical states of the human body and confusion of the Evenki mind, his ethnographic material, which he collected among the Evenki of the Amur region at the beginning of twentieth century, is relevant for this discussion, as it emphasizes that keeping a distance from the locality where the dead were buried was also a main concern in relation to the well-being of the living among the Evenki.

It is characteristic that, in spite of the imagined congruity of the world of the dead and the world of the living, the Eveny make a qualitative distinction between the two: they regard the other world as opposite to, different from, and wicked in comparison with the world of the living. They also damaged the belongings of the deceased because those objects too had to look "destroyed." In other words, they needed to show that these things were not being used by living humans. All objects in the other world mirror their inverted image in the world of the living. Nowadays, on graves, one can still see saucepans with holes in them, porcelain teapots without spouts, cups and saucers with broken edges. Personal belongings of the deceased, including saddles, sledges and ropes which were used to tie up reindeer, are damaged and put on the specially constructed wooden base or pedestal above a grave. Even the clothes in which the deceased are dressed have patches to make them unusable by the living, or else the deceased "will not find them", will wander around and prey on the living. In this context, any sort of trace left behind by the deceased, especially those who died as a result of physical violence, creates anxiety, and, in the particular case of the village, an abundance of the wandering spirits arinkael - generates a sense of an accursed space.

Ghosts of the Gulag represent a special case. Locals may deal with the deceased of local origin and prevent themselves from being disturbed by appeasing the dead, i.e. they feed 
the deceased by putting a shot of vodka, tea and food on their graves. By such gestures Eveny facilitate peaceful and non-disturbing behaviour of the spirits of the deceased. In contrast, Gulag ghosts do not respond to these rituals, and, above all, they have no human names for locals to address them by, and their graves cannot be located. Though Eveny classify all ghosts as arinkael, local dead and Gulag dead seem to manifest distinct degrees of otherness. Arinkael are former kinsmen who, by virtue of belonging to the world of the dead, have turned into predatory and malevolent spirits, but they are still conceived of as not-fully-other because they respond to the rituals. Gulag ghosts' full otherness is manifested in their unresponsiveness to ritual offerings. Therefore, their otherness has nothing to do with being of foreign origin but has to do with their making themselves alien, rejecting offerings and thus kinship relations.

\section{Cosmological entrapment}

The discourse on the village as an accursed space has been expressed in villagers' attempts to find a resolution to the situation with the Gulag ghosts ${ }^{43}$. In 2002 a couple of volunteers decided to invite an Orthodox priest in the hope that by conducting a special ritual of blessing he would calm unhappy ghosts and send them, according to their understanding, to the Orthodox world of the dead. Those volunteers deemed that the priest would supposedly match the ghosts' cosmology and exorcise and purify the area. However, after the priest from the Moscow Orthodox Church arrived and performed exorcism, people understood that exorcism did not

\footnotetext{
${ }^{43}$ According to Kangalas, an elderly informant and the son of the local shaman who died in 1970s, among local Eveny it used to be an exclusive activity of a shaman to comfort, treat respectfully and escort the spirits of the dead into the world of the dead. Powerful shamans would have been able to deal with these malevolent ghosts to at least keep them in check, if not to eliminate them, however, majority of shamans were persecuted by Soviet authorities, sent to prisons or violently killed (Balzer, Tenacity of Ethnicity (1993); Vitebsky, Reindeer People (2005).
} 
work because the ghosts were still in the buildings. Locals asked the priest why the ritual was not effective and he responded that it would not work until a chapel was built in the village. After the priest left, no one took charge of initiating a chapel's construction, as exorcism performed by the priest proved to be ineffective and was not convincing enough to start building.

This unsuccessful attempt eloquently shows that the situation with Gulag ghosts, and especially their cosmologically ambiguous character, has perplexed the local Eveny. I interpret their decision to involve the hierarchical figure of the Orthodox priest as an experimental switch from the Eveny immanent view of the afterlife to the Christian transcendence of the dead. That is to say, by giving the ghosts transcendental treatment, they had hoped to send the spirits away to the Christian realm of the dead. Ontologically, this move was essentially directed at vertical resolution of the cosmological conundrum, but instead of transporting them into the transcendental "heaven" with the help of the Russian priest, it re-inscribed the status of the ghosts in local cosmology immanently. Given the latter, it is possible to observe that violent deaths of Gulag prisoners in the vicinity created a sequence of blocked procedures. Namely, the dead, severely cut off from their kinship networks, were blocked from proper treatment of their deaths such as funeral, burial and bereavement rituals. Another blockage is related to the local population's vulnerability in dealing with an abundance of ghosts owing to their inability to get away from the fixed space associated with death. Both blockages represent a cosmological entrapment which threatens to engulf living humans into its deadly fold.

Given the abundance of ghosts in the village buildings, the only solution for locals to deal with the numerous unhappy arinkael became relocation of their households into different, more habitable buildings around the village. The process of out-migration as well as the intravillage movement has intensified, with a growing number of abandoned buildings in the village, 
the collapse of the infrastructure in the 1990s. Moreover, in late 1990s-early 2000s outmigration has drastically exceeded in-migration, leaving the settlement at risk of decline and even total abandonment ${ }^{44}$. This suggests that during the period of the state's generous support of the local infrastructure (the 1970s and 1980s) this sense of malevolence was not apparent. The village economy and infrastructure were strong and there were close links with the outside world through air transport, so local people could make frequent and regular flights to the regional capital. Flying back and forth in this way would allow one to stay mobile and not to feel trapped within a single social and geographical space. The collapse of this elaborate infrastructure which occurred in the 1990s generated a quite new sense of abandonment, and isolation from the outside world, and perhaps a more intense sense of place. What makes this case special is that the appearance of ghosts in local buildings and of stories related to them only became common in the early 1990s. This was the period of economic collapse when new (post-Gulag) settlers who had arrived to live in the village in Soviet times moved back to central parts of Russia and their places of origin ${ }^{45}$. By vacating houses and flats, they have left empty spaces which are being filled by the ghosts of previous generations of newcomers (Gulag prisoners) who represent the suffering on which the village was originally built.

In the course of the last decade, it has appeared that the ghosts have started taking over houses by pushing living humans out of the buildings. The villagers anxiously avoid cohabitation with ghosts and move out of haunted buildings in fear. The grounds for such fear lie in

\footnotetext{
44 Vinokurova, D. and M. N. Prokhorova, "The Quality of Life of the Population in the Republic of Sakha (Yakutia), the Example of MP "Tomponsky Area" and the Prospects for Raising its Level”, Voprosy Sovremennoi Ekonomiki UDK 314 (2011), no. 571: 56-67.
}

45 Thompson, Settlers on the Edge (2008). 
the ghosts' latent malevolence, as just like in the scenario of unnatural participation, a living person's substantial interaction with them may eventually lead to her/his losing human identity and transforming into an arinka. Since the Gulag ghosts overpower by taking over abandoned houses, it seems that the ghosts also succeed in converting the space for the living into the zone for the dead. The asymmetry of interaction between the living and the dead and its spatial dimension suggest that living humans expect that powerful ghosts may eventually succeed in converting them into one of them. By changing their places of residence, people follow similar nomadic strategy as in the forest, i.e. move away from such places, and by vacating their flats give away their accommodation to ghosts.

\section{Conclusion}

The scenario of unnatural participation described above implies that the latest collapse of the infrastructure and threat of abandonment generate the experience of cosmological entrapment expressed through the notion of vulnerable 'open body'. The Eveny notion of 'open body' and Deleuze and Guattari's concept of unnatural participation productively update Durkheimian theory of contagion by bringing symbiotic and spatial dimension to the understanding of the dynamic between the sacred and profane. The overlapping sites of the present residents and the former, unquiet dead create a specific scenario of contagion, namely, cosmological entrapment where the local population remain locked into a volatile relationship with the spirits of the deceased who suffered violent deaths in their area. The discussion illustrated that such scenario intensifies interactions between the local population and arinkael entangling the living in the mode of unnatural participation. While arinkael are engaged in a persistent quest for the space of their habitation and assertion of the boundary between the world of the living and the world of the dead, people's sense of entrapment conjures a new sense of "open-bodiedness". Therefore, 
the category of arinkael expands owing to conflation of Gulag ghosts with local arinkael which in its turn contribute to proliferation of the arinkael in the Eveny cosmology. As cosmological agents arinkael throw a multi-dimensional projection onto the space of the village: the space saturated with a sense of vulnerability of "open-bodiedness" (on the level of human personhood), the space of a nomadic camp imbued with powerful contagious spirithood of the dead (on the level of emic cosmology), and the former territory of the concentration camp (on the historical, genealogical level). Thus, the Gulag ghosts modify the Eveny perception of the world of the dead and, as a result, the scenario of unnatural participation of local Eveny and new type of arinkael expand the purview of the Eveny cosmology.

Finally, the assemblage of non-cognitive, non-linear types of analytical categories such as affect and contagion allowed the uncovering and the shedding of new light on how nowadays living humans engage with the Gulag legacy on a daily basis. The focus on the socially grounded interactions with visible and material traces of the Gulag may assist in overcoming barriers between present, past and future as well as dichotomies of recognized/unrecognized memories and valid/invalid evidence. My attention to local arinkael haunting the living helped to illuminate grey, fluid zone located somewhere in between oblivion and remembrance as they neither fully belong to the past nor entirely constitute a property of the present. The ethnographic material has shown that the proposed methodological focus on haunted space and relations between the living and the dead may potentially prevent a reified, essentialized take on memory of the tragic, violent past and reconcile the epistemological dilemma often faced by Gulag studies, i.e. the deficit of "reliable" data and the murkiness and inconsequentiality of the historical evidence.

Instead of treating the ghosts of the Gulag prisoners (arinkael) as a metaphor and 
cognitive reference to the past, I emphasized that the ghosts as affective residues of the Gulag actively participate in the process of cosmological modification and reproduction of the spatial construct of the former concentration camp. The latter dynamic co-creates, co-constitutes and mutually expands the Eveny cosmology. In other words, local Eveny provide a sociocosmological space for Gulag ghosts by moving out of the haunted locality because they fear being pulled into their world of the dead by predatory Gulag ghosts. Still, the ghosts do not seem to leave unless people vacate haunted buildings. Local 'open bodies' therefore become caught in the circular bind of an unwanted relationship with a Gulag ghost, which is a new, but impossible to appease, type of arinkael.

\section{REFERENCES}

Antze, Paul and Michael, Lambek (Eds.). Tense Past: Cultural Essays in Trauma and Memory. New York: Routledge. 1996.

Argenti, Nikolas and Katherine, Schramm (Eds). Remembering Violence: Anthropological Perspectives on Intergenerational Transmission. New York: Berghahn. 2010.

Balzer, Marjorie. Dilemmas of the Spirit: Religion and Atheism in the Yakut-Sakha Republic. In Religious Policy in the Soviet Union. S. P. Ramet ed. Pp. 231-251. Cambridge: Cambridge University Press. 1993.

Balzer, Marjorie. The Tenacity of Ethnicity: Siberian Saga in Global Perspective. Princeton: Princeton University Press. 1999. 
Bodenhorn, Barbara."He used to be my relative": Exploring the Bases of Relatedness among Inupiat of Northern Alaska. In Cultures of Relatedness: New Approaches to the Study of Kinship. J. Carsten ed. Pp. 128-148. Cambridge: Cambridge University Press. 2000.

Bogoras, Vlaidimir. Lamuty (iz nabludenyi v Kolymaskom krayui). Zemlevedeniye 1: 59-72. 1900.

Briggs, Jean. Inuit Morality Play: The Emotional Education of a Three-Year-Old. New Haven: Yale University Press. 1998.

Buyandelger, Manduhai. Tragic Spirits: Shamanism, Socialism, and the State of Neoliberalism in Mongolia. Chicago: University of Chicago Press. 2013.

Carsten, Janet. Ghosts of Memory: Essays on Remembrance and Relatedness. Oxford: Blackwell. 2007.

Cruikshank, Julie. Do Glaciers Listen? Local Knowledge, Colonial Encounters, and Social Imagination. Seattle: University of Washington Press. 2005.

Deleuze, Gille. and Felix, Guattari. A Thousand Plateaus: Capitalism and Schizophrenia. Trans. B. Massumi. London and New York: Continuum. 1987. 
Durkheim, Emile. The Elementary Forms of Religious Life. Trans. C. Cosman. Oxford: Oxford University Press. 2001 [1912].

Fausto, Carlos. Feasting on People: Eating Animals and Humans in Amazonia. Current Anthropology 48(4): 497-530. 2007.

Fedorov, Viktor. Vorota v kolimsky ad. Yakutia 7(20): 5. 2001.

Feuchtwang, Stephen. The Transmission of Traumatic Loss: A Case Study in Taiwan. In Remembering Violence: Anthropological Perspectives on Intergenerational Transmission. N. Argenti and K. Schramm eds. Pp. 229-250. New York: Berghahn. 2010.

Forsyth, James. 1994. A History of the Peoples of Siberia. Russia's North Asian Colony 15811990. Cambridge: Cambridge University Press.

Gheith, Jehanne. "I never talked": Enforced Silence, Non-narrative, Memory, and the Gulag. Mortality 12(2): 159-175. 2007.

Gheith, Jehanne. and Katherine, Jolluck. Gulag Voices: Oral Histories of Soviet Incarceration and Exile. New York: Palgrave Macmillan. 2011.

Gordillo, Gaston. Landscapes of Devils: Tensions of Place and Memory in the Argentinean Chaco. Durham, NC: Duke University Press. 2004. 
Gregory, Paul and V.V. Lazarev (Eds.). The Economics of Forced Labor: The Soviet Gulag. Stanford: Hoover Institution Press. 2003.

Jochelson, Vladimir. The Yukaghir and the Yukaghized Tungus. New York: American Museum of Natural History. 1926.

Kan, Sergei. Symbolic Immortality: The Tlingit Potlatch of the Nineteenth Century. Washington, DC: Smithsonian Institution Press. 1989.

Kapferer, Bruce. Introduction. Outside All Reason: Magic, Sorcery and Epistemology in Anthropology. Social Analysis 46(3): 1-30. 2002.

Kwon, Heonik. Ghosts of War in Vietnam. Cambridge: Cambridge University Press. 2008.

Lambek, Michael. The Weight of the Past: Living with History in Mahajanga, Madagascar. New York: Palgrave Macmillan. 2002.

Lambek, Michael. Memory in a Maussian Universe. In Memory Cultures: Memory, Subjectivity and Recognition. S. Radstone and K. Hodgkin eds. Pp. 202-216. New Brunswick: Transaction Books. 2006.

Lavrillier, Alexandra. Nomadisme et adaptations sédentaires chez les Evenks de Sibérie postsoviétiques: "Jouer" pour vivre avec et sans chamanes. Paris: Ecole Pratique des Hautes Etudes. 
Mauzé, Marie. The Concept of the Person and Reincarnation among the Kwakiutl Indians. In Amerindian Rebirth: Reincarnation Belief among North American Indians and Inuit. A. Mills and R. Slobodin eds. Pp. 177-191. Toronto: University of Toronto Press. 1994.

Morrow, Phyllis. Yupik Eskimo Agents and American Legal Agencies: Perspectives on Compliance and Resistance. Journal of the Royal Anthropological Institute (N.S.) 2: 405-423. 1996.

Mueggler, Eric. The Age of Ghosts: Memory, Violence, and the Place in Southwest China. Berkeley: University of California Press. 2001.

Nikolaev, Semen. Eveny i evenki jugo-vostochnoi Jakutii. Yakutsk: Yakutskoje knijnoje izdatelstvo. 1964.

Pedersen, Morten. Not Quite Shamans: Spirit Worlds and Political Lives in Northern Mongolia. Ithaca: Cornell University Press. 2011.

Popova, Ulyana. Eveny Magadanskoi oblasti. Moscow: Nauka. 1981.

Shirokogoroff, Sergei. Psychomental Complex of the Tungus. Berlin: Shletzer. 2005 [1935].

Sirina, Anna. Eveny i Evenki v sovremennom mire: samosoznaniye, prirodopol'zovaniye, 
mirovozzreniye. Mosow: Vostochnaya Literature. 2012.

Slezkine, Yuri. Arctic Mirrors: Russia and the Small Peoples of the North. Ithaca: Cornell University Press. 1994.

Ssorin-Chaikov, Nikolai. Evenky Shamanistic Practices in Soviet Present and Ethnographic Present Perfect. Anthropology of Consciousness 12(1): 1-18. 2001.

Ssorin-Chaikov, Nikolai. The Social Life of the State in Subarctic Siberia. Stanford: Stanford University Press. 2003.

Sirina, A. Eveny i Evenki v sovremennom mire: smosoznaniye, prirodopol'zovaniye, mirovozzreniye. Mosow: Vostochnaya Literature. 2012.

Swancutt, Katherine. The Undead Genealogy: Omnipresence, Spirit Perspectives, and a Case of Mongolian Vampirism. Journal of the Royal Anthropological Institute (N.S.) 14: 843-864. 2008.

Swancutt, Katherine. Masked Predation, Hierarchy and the Scaling of Extractive Relations in Inner Asia and Beyond. In Animism in Rainforest and Tundra: Personhood, Animals, Plants and Things in Contemporary Amazonia and Siberia. M. Brightman, V. E. Grotti and O.

Ulturgasheva. eds. Pp. 293-326. New York: Berghahn. 2012.

Swancutt, Katherine. Fortune and the Cursed: The Sliding Scale of Time in Mongolian 
Divination. New York: Berghahn.2012.

Thompson, Niobi. Settlers on the Edge: Identity and Modernization on Russia's Arctic Frontier. Vancouver: University of British Columbia Press. 2008.

Ulturgasheva, Olga. 2012. Narrating the Future in Siberia: Childhood, Adolescence and Autobiography among the Eveny. 2012. Oxford, New York: Berghahn Books.

Ulturgasheva, Olga. 2015. "Gulag Legacy: Spaces of Continuity in Contemporary Everyday Practices." In Ulturgasheva, O. (Ed.). Special issue of Laboratorium. Thematic issue: Gulag legacy: Spaces of Continuity in Everyday Practice. 7 (1): 5-14.

Ulturgasheva, Olga. 2016. Spirit of the Future: Movement, Kinetic Distribution and Personhood among Siberian Eveny. In Social Analysis 60 (1): 56-73.

Ulturgasheva, Olga. 2016. "Haunting Afterlives of the Gulag in the Siberian Sub-Arctic." Hot Spots Cultural Anthropology website, July 29, 2016. https://culanth.org/fieldsights/940-hauntingafterlives-of-the-gulag-in-the-siberian-sub-arctic.

Vilaca, Aparecida. Chronically Unstable Bodies: Reflections on Amazonian Corporalities. Journal of the Royal Anthropological Institute (N.S.) 11: 445-464. 2005.

Vinokurova, Daria and M. N. Prokhorova. The Quality of Life of the Population in the Republic of Sakha (Yakutia), the Example of MP "Tomponsky Area" and the Prospects for Raising its 
Level. Voprosy Sovremennoi Ekonomiki UDK 314(571): 56-67. 2011.

Vitebsky, Piers. Reindeer People: Living with Animals and Spirits in Siberia. London: HarperCollins. 2005.

Willerslev, Rane. Soul Hunters: Hunting, Animism, and Personhood among the Siberian Yukaghirs. Berkeley: University of California Press. 2007.

Willerslev, Rane. The Optimal Sacrifice: A Study of Voluntary Death among the Siberian Chukchi. American Ethnologist 36(4): 693-704. 2009.

Willerslev, Rane and Olga, Ulturgasheva. Revisiting the Animism versus Totemism Debate: Fabricating Persons among Eveny and Chukchi of Northeastern Siberia. In Animism in Rainforest and Tundra: Personhood, Animals, Plants and Things in Contemporary Amazonia and Siberia. M. Brightman and V. E. Grotti eds. Pp. 84-119. New York: Berghahn. 2012. 